\title{
PENGARUH IKLAN RADIO TERHADAP PILIHAN RESTORAN PARA KOMUTER YANG DIMODERASI OLEH SIKAP DAN PENCARIAN INFORMASI
}

\author{
I Putu Gisna Da Silva Kusuma ${ }^{1}$ \\ Geda Bayu Rahanatha ${ }^{2}$ \\ ${ }^{1,2}$ Fakultas Ekonomi dan Bisnis Universitas Udayana (Unud), Bali, Indonesia \\ Email: gisna.dasilva@yahoo.co.id
}

\begin{abstract}
ABSTRAK
Iklan radio adalah segala bentuk penyajian non-personal dan promosi ide, barang atau jasa yang memerlukan pembayaran dan disebarluaskan melalui media radio. Tujuan dari penelitian ini untuk meneliti pengaruh iklan radio terhadap pilihan restoran para komuter yang dimoderasi oleh sikap dan pencarian informasi. Penelitian ini dilakukan terhadap para komuter yang bepergian menggunakan kendaraan roda empat dari atau ke Kota Denpasar. Sampel penelitian adalah sebanyak 132 responden. Kuisioner menjadi sarana pengumpulan data pada penelitian ini. Teknik pengolahan data dalam penelitian ini adalah Moderated Regression Analysis (MRA) dengan program SPSS. Berdasarkan hasil pengolahan data diketahui bahwa iklan radio memiliki pengaruh yang positif signifikan terhadap pilihan restoran para komuter. Sikap memperkuat pengaruh iklan radio terhadap pilihan restoran. Pencarian informasi memperkuat pengaruh iklan radio terhadap pilihan restoran.

Kata kunci : iklan radio, sikap, pencarian informasi, pilihan restoran
\end{abstract}

\begin{abstract}
Radio advertising is all forms of non-personal presentation and promotion of ideas, goods or services that require payment and disseminated through radio media. The purpose of this study was to examine the effect of radio advertising on the choice of restaurant commuters which was moderated by attitude and information seeking. This research was conducted on commuters who traveled using four-wheeled vehicles from or to Denpasar City. The research sample was 132 respondents. Questionnaires became a means of collecting data in this study. The data processing technique in this study is the Moderated Regression Analysis (MRA) with the SPSS program. Based on the results of data processing, it is known that radio advertising has a significant positive influence on the choice of restaurant commuters. The attitude strengthens the influence of radio advertising on restaurant choices. Information seeking strengthens the influence of radio advertising on restaurant choices.
\end{abstract}

Keywords: radio advertising, attitude, information search, restaurant choice 


\section{PENDAHULUAN}

Jumlah kendaraan bermotor di Indonesia terus meningkat setiap tahunnya. Berdasarkan data dari situs resmi Badan Pusat Statistik (2016), jumlah kendaraan jenis mobil penumpang di Indonesia ditahun 2014, 2015 dan 2016 adalah $12.599 .038,13.480 .973,14.580 .666$ kendaraan, meningkat rata-rata 1 juta kendaraan setiap tahunnya.

Ini menunjukkan bahwa jumlah pengguna mobil penumpang terus bertambah bertambah setiap harinya dan menjadi bagian dari rutinitas seharihari termasuk untuk bepergian maupun bekerja. Orang yang bepergian setiap hari ke suatu kota atau wilayah untuk bekerja atau beraktivitas dan kembali ke kota tempat tinggalnya yang cukup jauh disebut sebagai komuter.

Menurut hasil penelitian Loechner (2016) di Orlando, Amerika Serikat, 9 dari 10 komuter yang menggunakan mobil mendengarkan radio AM / FM saat berada di mobil mereka dalam perjalanan untuk bekerja, dengan presentase mendengarkan radio AM / FM (62\%), mendengarkan file musik digital sendiri ( 54\%) dan streaming radio internet (42\%) sebagai bentuk yang paling umum selama perjalanan.

Hal ini menunjukkan bahwa radio masih menjadi media yang berpeluang tinggi untuk menyebarkan informasi, salah satunya adalah melalui iklan. Periklanan merupakan segala bentuk penyajian non-personal dan promosi ide, barang, atau jasa oleh suatu sponsor tertentu yang memerlukan pembayaran. Iklan radio bisa sangat kreatif. Kelemahan tidak adanya gambar visual dapat menjadi nilai tambah dengan penggunaan musik, suara, dan perangkat kreatif lainnya dengan cerdas yang dapat membangun imajinasi pendengar untuk menciptakan gambar yang sangat relevan dan disukai (Kotler \& Keller, 2012:509)

Sikap pendengar yang sekaligus menjadi konsumen potensial juga berpengaruh terhadap efektivitas iklan radio tersebut. Sikap dalam istilah pemasaran didefinisikan sebagai evaluasi umum terhadap produk atau layanan yang terbentuk dari waktu ke waktu. Sikap menunjukkan motif pribadi dan pada saat bersamaan, mempengaruhi kebiasaan berbelanja dan membeli konsumen. Sikap konsumen sebagai gabungan antara keyakinan konsumen (beliefs), perasaan (feelings), dan niat perilaku (behaviralintentions) terhadap beberapa objek dalam konteks pemasaran (Perner, 2010). Konsumen dapat memegang keyakinan atau perasaan yang negatif maupun positif terhadap suatu produk atau jasa. Niat perilaku didefinisikan oleh kepercayaan atau perasaan konsumen sehubungan dengan produk atau jasa tersebut.

Menurut Kotler \& Keller (2012:166), pencarian informasi adalah tahapan kedua setelah pengenalan kebutuhan (need recognition) dalam proses keputusan pembelian. Secara mengejutkan, konsumen sering mencari informasi dalam jumlah yang terbatas. Iklan radio menjadi salah satu sumber informasi yang dapat mempengaruhi keputusan pembelian yang akan dilakukan konsumen.

Tahapan ketiga dalam proses keputusan pembelian adalah evaluasi alternatif (evaluation of alternatives). Restaurant choice atau pilihan restoran dihasilkan dari sebuah proses dimana informasi tentang berbagai alternatif 
dievaluasi oleh konsumen sebelum memilih salah satu alternatif ini (Kotler \& Keller, 2012:166). Dalam penelitian ini akan dibahas pengaruh iklan radio yang dimoderasi sikap dan pencarian informasi terhadap pilihan restoran para komuter.

Penelitian ini akan menguji iklan radio yang disiarkan radio-radio di Bali. Menurut pra survei yang dilakukan, dari 20 responden, 95\% pernah mendengarkan iklan radio selama perjalanan, $80 \%$ merasa senang mendengarkan iklan radio, $90 \%$ merasa mendapatkan informasi dari iklan radio yang didengarkan dan sebesar $70 \%$ merasa iklan radio yang didengarkan mempengaruhi pilihan restoran mereka.

Beberapa peneliti yang pernah meneliti pengaruh iklan radio terhadap pilihan restoran dengan keterkaitan variabel sikap dan pencarian informasi diantaranya adalah Rajagopal (2011), Volle (2001), Wahid \& Ahmed (2011), Kaushal \& Rakesh (2016), Ansari \& Joloudar (2014), Auty (2006), Hsu \& Mo (2009) dan Rosenbloom \& Jiang (2014) Berdasarkan latar belakang permasalahan yang dibahas serta acuan studi-studi terdahulu, maka penelitian ini membahas hubungan empat variabel yaitu iklan radio, sikap, pencarian informasi dan pilihan restoran.

Berdasarkan latar belakang permasalahan yang telah dibahas, dapat dirumuskan permasalahan penelitian ini adalah sebagai berikut. Bagaimanakah pengaruh iklan radio terhadap pilihan restoran para komuter. Bagaimanakah pengaruh sikap dalam memoderasi pengaruh iklan radio terhadap pilihan restoran para komuter. Bagaimanakah pengaruh pencarian informasi dalam memoderasi pengaruh iklan radioterhadap pilihan restoran para komuter.

Hasil penelitian ini tidak hanya memberikan kegunaan yang dapat dirasakan oleh penulis saja melainkan memberikan kegunaan terhadap elemen atau pihak-pihak yang terkait dalam penelitian ini, baik secara langsung maupun tidak langsung. Selain itu diharapkan juga agar dapat menambah bukti empiris tentang studi yang membahas hubungan antara iklan radio, sikap, pencarian informasi dan pilihan restoran para komuter sehingga dapat digunakan sebagai referensi untuk melakukan studi selanjutnya. Hasil penelitian ini juga diharapkan dapat menjadi informasi dan bahan pertimbangan pengambilan keputusan bagi pemasar ketika ingin membuat iklan radio.

Periklanan menurut Kotler \& Keller (2012:418) didefinisikan sebagai segala bentuk penyajian non-personal dan promosi ide, barang, atau jasa oleh suatu sponsor tertentu yang memerlukan pembayaran. Iklan radio adalah iklan yang disebarluaskan melalui media radio.

Menurut Oakes \& North (2011), iklan radio lebih dipilih daripada iklan televisi karena mampu mengurangi stimulus visual yang mengganggu dan membantu memusatkan perhatian pada suara iklan itu sendiri tanpa bukti visual.

Iklan radio sering menggunakan musik instrumental sebagai latar belakang ketika menyampaikan pesan verbal. Latar belakang musik ini ditujukan untuk menarik perhatian lebih besar pada iklan agar pengiklan dapat menekankan pesan yang disampaikan (Roehm, 2001)

Iklan radio bisa sangat kreatif. Kelemahan tidak adanya gambar visual dapat menjadi nilai tambah dengan penggunaan musik, suara, dan perangkat 
kreatif lainnya dengan cerdas yang dapat membangun imajinasi pendengar untuk menciptakan gambar yang sangat relevan dan disukai (Kotler \& Keller, 2012:509)

Sikap yaitu evaluasi dalam waktu lama tentang apa yang disukai atau tidak disukai seseorang, perasaan emosional, dan kecenderungan tindakan terhadap beberapa objek atau ide (Kotler \& Keller, 2012:168). Sikap adalah kecenderungan yang dipelajari dalam berperilaku dengan cara menyenangkan atau tidak menyenangkan terhadap suatu objek tertentu.

Sikap juga didefinisikan sebagai ekspresi seseorang yang mengungkapkan rasa suka maupun tidak pada suatu objek. Sikap seseorang dan perilakunya sangat berhubungan, dimana jika seseorang mempunyai sikap yang positif maka perilaku yang ditimbulan juga akan positif

Sikap dalam istilah pemasaran didefinisikan pula sebagai evaluasi umum terhadap produk atau layanan yang terbentuk dari waktu ke waktu. Sikap menunjukkan motif pribadi dan pada saat bersamaan, mempengaruhi kebiasaan berbelanja dan membeli konsumen. Sikap konsumen sebagai gabungan antara keyakinan konsumen (beliefs), perasaan (feelings), dan niat perilaku (behaviralintentions) terhadap beberapa objek dalam konteks pemasaran (Perner, 2010).

Konsumen dapat memegang keyakinan atau perasaan yang negatif maupun positif terhadap suatu produk atau jasa. Niat perilaku didefinisikan oleh kepercayaan atau perasaan konsumen sehubungan dengan produk atau jasa tersebut.

Menurut Kotler \& Keller (2012:166), pencarian informasi adalah tahapan kedua setelah pengenalan kebutuhan (need recognition) dalam proses keputusan pembelian dimana konsumen mencari informasi dari berbagai sumber.

Köksal (2011) menyatakan, meskipun pencarian informasi oleh konsumen terkait dengan aktivitas pra-pembelian, namun konsumen selalu mencari informasi di lain waktu dan karena alasan lain. Dalam ekonomi informasi tradisional, konsumen terlibat dalam pencarian informasi yang aktif sampai biaya marjinal yang dirasakan dari unit pencarian tambahan melebihi manfaat marjinal yang diharapkan.

Konsumen biasanya terlibat dalam pengalaman internal (memori atau pengalaman masa lalu) atau eksternal (memeriksa periklanan, kemasan produk atau label) dalam mencari informasi dan umumnya dimulai dengan informasi internal yang tersedia. Jika pencarian informasi internal tidak cukup, mereka beralih ke sumber eksternal.

Pencarian informasi eksternal sebagai tingkat perhatian, persepsi dan upaya yang ditujukan untuk memperoleh data lingkungan atau informasi yang berkaitan dengan pembelian tertentu yang sedang dipertimbangkan. Sumber informasi eksternal dapat diklasifikasikan sebagai sumber yang didominasi dan didominasi oleh pemasar dan sumber informasi pribadi, komersial, publik dan eksperiensial (Köksal, 2011)

Pencarian informasi bergantung pada kemampuan dan motivasi individu, dan kedua faktor tersebut diperlukan untuk memperoleh informasi melalui 
pencarian yang mudah dilakukan. Perilaku pencarian individu dibatasi oleh pengetahuan individu tersebut mengenai bagaimana memproses informasi, dan juga kemampuan untuk mengumpulkan jumlah informasi yang sesuai (Yeoh, 2005)

Restaurantchoice atau pilihan restoran dihasilkan dari sebuah proses dimana informasi tentang berbagai alternatif dievaluasi oleh konsumen sebelum memilih salah satu alternatif ini (Kotler \& Keller, 2012:166). Perilaku pilihan restoran konsumen sangat mirip dengan perilaku pilihan merek konsumen, perbedaannya adalah adanya penggabungan dimensi spasial pada pilihan restoran (Tripathi \& Sinha, 2008)

Sebuah model pilihan restoran berasal dari survei konsumen yang mendukung strategi persaingan pemilik restoran, konsumen mengatakan bahwa jenis makanan dan kualitas makanan adalah variabel utama dari pilihan restoran, setelah menentukan pilihan makanan dan segment restoran, gaya dan atmosfer restoran menjadi faktor penentu selanjutnya. Selain itu, positioning dan iklan adalah hal yang juga paling mungkin memengaruhi pilihan restoran (Auty, 2006)

Pilihan restoran bergantung pada ukuran dan jarak (daya tarik gravitasi), serta preferensi individu terhadap atribut restoran (daya tarik restoran dan sikap) (Volle, 2001)

Pilihan restoran konsumen juga mengacu pada prioritas hirarkis konsumen dari restoran sebagai akibat dari patronase restoran tersebut, yang meliputi kecenderungan konsumen untuk berbelanja di restoran tersebut dibandingkan restoran-restoran lainnya (Thang \& Tan, 2003)

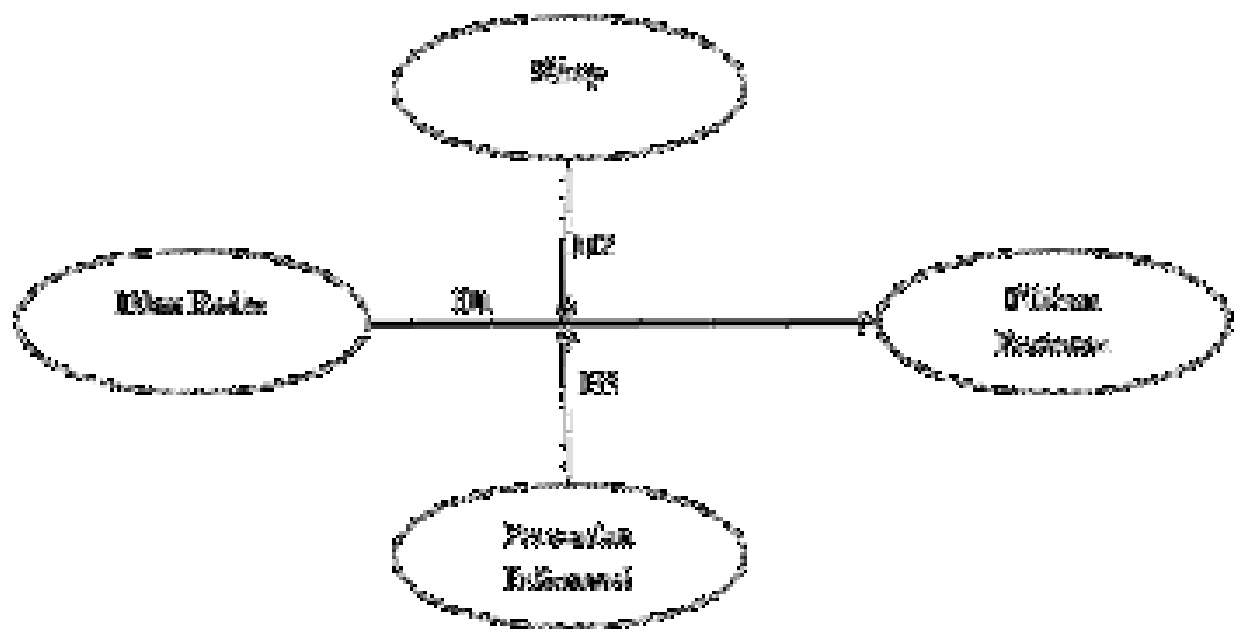

Gambar 1. Kerangka Penelitian

Rajagopal (2011) menyatakan bahwa iklan radio menembus dengan cepat dan memberi efek positif pada pendengar untuk menentukan pilihan toko atau restoran dan probabilitas pembelian. Volle (2001) menyatakan bahwa iklan radio memiliki efek positif pada probabilitas pilihan restoran.

Raju \& Devi (2012) menyatakan iklan radio harus jelas dan terdengar untuk memotivasi faktor-faktor untuk mempengaruhi perilaku pembelian 
pelanggan. Mode iklan radio juga memiliki preferensi yang lebih tinggi dengan kelompok usia 30-40 dan 50 tahun ke atas.

Auty (2006) menyatakan positioning dan iklan juga merupakan hal yangpaling mungkin memengaruhi pilihan restoran para konsumen. Berdasarkan kajian empiris sebelumnya, maka dapat disusun hipotesis sebagai berikut.

$\mathrm{H}_{1}$ : Iklan radio berpengaruh positif dan signifikan terhadap pilihan restoran.

Rajagopal (2011) menyatakan bahwa iklan radio berbasis harga sangat komprehensif yang merangsang probabilitas pilihan restoran dan membangun sikap konsumen yang baik terhadap pembelian produk pada promosi. Volle (2001) menyatakan bahwa efek dari jumlah produk yang diiklankan pada probabilitas pilihan restoran akan lebih tinggi bagi pelanggan dengan sikap yang baik terhadap pembelian produk pada promosi.

Wahid \& Ahmed (2011) menyatakan bahwa sikap konsumen terhadap periklanan berpengaruh signifikan dan positif atas niatnya untuk membeli produk yang diiklankan. Kaushal \& Rakesh (2016) menyatakan bahwa sikap terhadap iklan secara positif signifikan mempengaruhi niat beli. Ansari \& Joloudar (2014) menyatakan bahwa ada pengaruh positif antara sikap konsumen terhadap iklan produk musim dingin T.V. Berdasarkan kajian empiris sebelumnya, maka dapat disusun hipotesis sebagai berikut.

$\mathrm{H}_{2}$ : Sikap memoderasi pengaruh iklan radio terhadap pilihan restoran secara positif

Rajagopal (2011) menyatakan bahwa penyiaran iklan di radio memberi dampak positif bagi penumpang perkotaan untuk memahami komunikasi dengan memperhatikan dan berbagi informasi yang menunjukkan kesadaran akan isi komunikasi. Volle (2001) menyatakan bahwa efek dari jumlah produk yang diajukan dalam selebaran pada probabilitas pilihan restoran akan lebih tinggi bagi pelanggan yang mengklaim mencari informasi promosi.

Hsu \& Mo (2009) menyatakan bahwa keterlibatan konsumen secara positif mempengaruhi tingkat pencarian informasi. Rosenbloom \& Jiang (2014) menyatakan bahwa ada hubungan positif antara pengetahuan obyektif dan pencarian informasi eksternal.

Pedraja \& Yague (2001) menjelaskan bahwa langkah pertama untuk keberhasilan mencocokkan kebutuhan konsumen adalah dengan mendapatkan pemahaman komprehensif tentang pencarian informasi yang dilakukan oleh konsumen dan informasi aktual yang digunakan ketika memilih restoran. Marta (2001) menguji faktor motivasi pelanggan terkait dengan pencarian informasi eksternal mereka ketika memilih restoran.

Hasilnya mengacu pada dua sumber informasi yang disediakan oleh restoran: sumber informasi yang disediakan melalui iklan (seperti iklan yang ditempatkan di majalah, internet, radio, atau jendela restoran) dan bagaimana informasi yang disediakan melalui elemen yang nyata (dekorasi, suara, cahaya, dan menu pintu) yang memainkan peran dalammenentukan pilihan restoran oleh pelanggan.

Berdasarkan kajian empiris sebelumnya, maka dapat disusun hipotesis sebagai berikut. 
$\mathrm{H}_{3}$ : Pencarian informasi memoderasi pengaruh iklan radio terhadap pilihan restoran secara positif

\section{METODE PENELITIAN}

Jenis penelitian ini digolongkan ke dalam penelitian asosiatif yaitu pengaruh antara variabel sikap dan variabel pencarian informasi dalam memoderasi iklan radio, serta variabel iklan radio terhadap pengaruh pilihan restoran yang dimoderasi oleh sikap dan pencarian informasi.

Penelitian ini dilakukan dengan meneliti iklan radio yang disiarkan oleh radio-radio di Bali yang didengarkan oleh komuterdari atau ke Denpasar.

Lokasi ini dipilih karena Denpasar merupakan ibu kota Provinsi Bali dimana terdapat pusat pemerintahan, pendidikan, kesehatan dan lain-lain yang menyebabkan Kota Denpasar memiliki kepadatan lalu lintas yang tinggi setiap harinya. Hal ini didukung dengan data gerbang tol Bali Mandara di awal tahun 2018 yang menunjukkan volume kendaraan yang melalui tol mencapai lebih dari 10.000 kendaraan setiap harinya.

Obyek dalam penelitian ini adalah pengaruh iklan radio $\left(\mathrm{X}_{1}\right)$ yang dimoderasi sikap $\left(\mathrm{X}_{2}\right)$ dan pencarian informasi $\left(\mathrm{X}_{3}\right)$ terhadap pilihan restoran $\left(\mathrm{Y}_{1}\right)$ para komuter. Subyek dalam penelitian ini adalah para komuter yang bepergian dari Denpasar dan menempuh perjalanan minimal 30 menit setiap harinya.

Variabel bebas adalah variabel yang menjadi sebab timbulnya atau berubahnya variabel terikat. Variabel bebas dalam penelitian ini adalah iklan radio yang disimbulkan dengan $\mathrm{X}_{1}$.

Variabel moderasi adalah variabel yang bersifat memperkuat atau memperlemah pengaruh variabel bebas terhadap variabel terikat. Variabel moderasi dalam penelitian ini adalah sikap yang disimbolkan dengan $\mathrm{X}_{2}$ dan pencarian informasi yang disimbolkan dengan $\mathrm{X}_{3}$.

Variabel terikat adalah variabel yang dipengaruhi atau yang menjadi akibat karena adanya variabel bebas. Variabel terikat dalam penelitian ini adalah pilihan restoran yang disimbulkan dengan $\mathrm{Y}_{1}$.

Iklan radio adalah variabel dalam penelitian ini. Iklan radio diukur dalam empat indikator yaitu AIDA (Attention, Interest, Desire dan Action).

Sikap yaitu evaluasi dalam waktu lama tentang apa yang disukai atau tidak disukai seseorang, perasaan emosional, dan kecenderungan tindakan terhadap beberapa objek atau ide. Dalam penelitian ini, sikap diukur dalam dua dimensi yaitu kognitif dan afektif.

Pencarian informasi adalah tahapan kedua setelah pengenalan kebutuhan (need recognition) dalam proses keputusan pembelian dimana konsumen mencari informasi dari berbagai sumber.

Restaurant choice atau pilihan restoran dihasilkan dari sebuah proses dimana informasi tentang berbagai alternatif dievaluasi oleh konsumen sebelum memilih salah satu alternatif ini.

Data kualitatif dalam penelitian ini berupa identitas responden, simpulan hasil penelitian sebelumnya, dan teori-teori pendukung variabel. Data kuantitatif dalam 
penelitian ini adalah jumlah kendaraan bermotor di Indonesia, jumlah responden, hasil olah data SPSS kuisioner responden.

Sumber Primer, dalam penelitian ini adalah hasil kuesioner responden yaitu komuter yang bepergian sambil mendengarkan radio dari Denpasar dan menempuh minimal 30 menit perjalanan. Sumber Sekunder, dalam penelitian ini adalah Badan Pusat Statistik (BPS), surat kabar dan jurnal-jurnal penelitian sebelumnya.

Populasi dalam penelitian ini adalah seluruh komuter yang mendengarkan radio saat bepergian. Jumlah populasi dalam penelitian ini tidak dapat ditentukan secara pasti atau infinite. Sampel yang diambil dalam penelitian ini adalah komuter yang mendengarkan radiodi Bali selama perjalanan yang berjumlah 132 orang. Dalam penelitian ini digunakan 22 indikator sehingga banyaknya responden yang digunakan untuk sampel adalah (6 x $22=132$ orang). Sehingga, ukuran sampel 132 responden sudah dikategorikan layak.

Metode penentuan sampel yang digunakan dalam penelitian ini adalah non probability sampling dengan teknik purposive sampling. Purposive sampling adalah teknik penentuan sampel dengan pertimbangan tertentu.

Kriteria yang digunakan dalam menentukan responden pada penelitian ini adalah sebagai berikut: 1) Pendidikan minimal responden adalah SMA/SMK/sederajat. 2) Responden adalah komuter yang bepergian menggunakan kendaraan roda empat dari Denpasar dan menghabiskan waktu minimal 30 menit sekali perjalanan. 3) Responden adalah komuter yang mendengarkan radio selama diperjalanan.

Pengumpulan data pada penelitian ini menggunakan metode yang diakukan dengan survei menyebarkan kuisioner kepada responden yang memenuhi kriteria. Peneliti secara langsung menyebarkan kuisioner kepada responden dengan bantuan oleh teman dan kerabat dekat. Pengukuran kuisioner menggunakan skala likert dengan skala 1 sampai dengan 5 .

Uji validitas instrumen dalam penelitian ini menggunakan pra survey yang melibatkan 20 responden. Jumlah 20 responden adalah jumlah minimal untuk melakukan pra survey untuk menguji validitas instrument penelitian.

Dari 20 responden, 95\% pernah mendengarkan iklan radio, 80\% merasa senang mendengarkan iklan radio, 90\% merasa mendapatkan informasi dari iklan radio yang didengarkan dan sebesar $70 \%$ merasa iklan radio yang didengarkan mempengaruhi pilihan restoran mereka.

Teknik analisis data merupakan teknik pengolahan data yang telah dikumpulkan yang nantinya menghasilkan suatu informasi yang digunakan untuk menjawab masalah-masalah yang telah dirumuskan dalam penelitian.

Teknik analisis data yang digunakan dalam penelitian ini adalah moderated regression analysis dengan menggunakan program SPSS. Model regresi yang memenuhi persyaratan sebagai model empiris yang baik adalah model yang telah berhasil melewati searangkaian uji asumsi klasik. Uji asumsi klasik terdiri dari uji normalitas, uji multikolinieritas, uji autokorelasi, dan uji heteroskedastisitas.

Teknik analisis data yang digunakan adalah teknik regresi dengan moderasi maka tidak perlu melakukan uji multikolonieritas. Multikolonieritas tidak terjadi masalah ketika menerapkan analisis regresi moderasian, sehingga hanya perlu dilakukan pengujian normalitas data, uji autokorelasi, dan uji heteroskedastisitas. 
Analisis Moderasi Regresi atau Moderated Regression Analysis (MRA) bertujuan untuk mengetahui peran suatu variabel yang dapat memperkuat atau memperlemah korelasi antara suatu variabel bebas (independen) terhadap variabel terikat (dependen) dengan rumus persamaan berikut.

$Y=\alpha+\beta_{1} X_{1}+\beta_{2} X_{2}+\beta_{3} X_{3}+\beta_{4} X_{1} * X_{2}+\beta_{5} X_{1} * X_{3+\varepsilon}$

Keterangan:

Y

A : Konstanta

$\mathrm{X}_{1} \quad$ : Iklan radio

$\mathrm{X}_{2} \quad$ : Sikap

$\mathrm{X}_{3} \quad$ : Pencarian informasi

$\mathrm{X}_{1} * \mathrm{X}_{2} \quad$ : Interaksi antara iklan radio dan sikap

$\mathrm{X}_{1} * \mathrm{X}_{3} \quad$ : Interaksi antara iklan radio dan pencarian informasi

$\beta_{1-} \beta_{5} \quad$ : Koefisien Regresi

e $\quad$ : Variabel pengganggu

Dari hasil analisis yang dilakukan selanjutnya diamati mengenai uji kelayakan model (uji F), koefisien determinasi (adjusted $R^{2}$ ) dan uji hipotesis (uji t).

\section{HASIL DAN PEMBAHASAN}

Radio pertama kali ditemukan oleh seorang ilmuan yang bernama Guglielmo Marconi dan terus berkembang hingga saat ini. Stasiun radio yang pertama berdiri di Indonesia adalah BRV atau Bataviase Radio Vereniging di Batavia (Jakarta) pada tahun 1925. Sejak saat itu, radio terus berkembang di Indonesia hingga ke Bali dan di tahun 2019 tercatat ada 66 stasiun radio di Bali, 2 radio AM dan FM

Penelitian ini dilakukan untuk mengetahui pengaruh iklan radio terhadap pilihan restoran para komuter yang dimoderasi oleh sikap dan pencarian informasi. Pengumpulan data dilakukan melalui penyebaran kuesioner kepada 132 komuter yang bepergian dari atau ke Denpasar.

Penyebaran kuesioner hingga semua kuesioner terjawab dan terkumpul kembali pada penelitian ini menghabiskan waktu 2 hari yaitu mulai tanggal 15 Januari sampai 16Januari 2019.

Berdasarkan Tabel 1. dapat dijelaskan bahwa kuesioner yang disebar sebanyak 132 lembar eksemplar dengan tingkat pengembalian 100\% sehingga total kuesioner yang digunakan sebanyak 132 lembar.

Karakteristik responden penelitian ini merupakan profil dari 132 responden yang berpartisipasi dalam pengisian kuesioner. Karakteristik responden penelitian meliputi jenis kelamin, umur, jenjang pendidikan, dan lama bekerja. Karakteristik responden dapat dilihat pada Tabel 2, Tabel 3, Tabel 4, Tabel 5, dan Tabel 6. 
Tabel 1.

Rincian Pengiriman dan Pengembalian Kuesioner

\begin{tabular}{lc}
\hline \multicolumn{1}{c}{ Keterangan } & Jumlah \\
\hline Kuesioner yang disebar & 132 \\
Kuesioner yang tidak kembali & 0 \\
Kuesioner yang dikembalikan & 132 \\
Kuesioner yang digunakan & 132 \\
Tingkat Pengembalian (Respons rate): & $100 \%$ \\
Kuesioner yang dikembalikan x 100\% & \\
Kuesioner yang dikirim & \\
Tingkat Pengembalian yang digunakan (useable response rate): & $100 \%$ \\
Kuesioner yang diolah x 100\% & \\
\hline Kuesioner yang dikirm &
\end{tabular}

Tabel 2.

Karakteristk Responden Berdasarkan Jenis Kelamin

\begin{tabular}{ccc}
\hline Jenis Kelamin & Jumlah (orang) & Persentase (\%) \\
\hline Laki - Laki & 51 & 38,64 \\
Perempuan & 81 & 61,36 \\
Total & $\mathbf{1 3 2}$ & $\mathbf{1 0 0}$ \\
\hline
\end{tabular}

Sumber : Data diolah, 2019

Tabel 2. menunjukkan proporsi komuter laki - laki dan perempuan berdasarkan jenis kelamin. Pada tabel 2 dapat diketahui jumlah komuter laki - laki sebanyak 51 orang responden $(38,64 \%)$ dan komuter perempuansebanyak 81 orang $(61,36 \%)$.

Informasi ini memberikan gambaran bahwa komuter yang bepergian untuk bekerja dan beraktivitas secara rutin menggunakan kendaraan roda empat dari Denpasar atau ke Denpasar dalam penelitian ini mayoritas adalah perempuan.

Tabel 3.

Karakteristik Responden Berdasarkan Umur

\begin{tabular}{ccc}
\hline Umur & Jumlah (orang) & Persentase (\%) \\
\hline $21-30$ tahun & 58 & 46,21 \\
$31-40$ tahun & 32 & 31,82 \\
$>40$ tahun & 29 & 21,97 \\
Total & $\mathbf{1 3 2}$ & $\mathbf{1 0 0}$ \\
\hline
\end{tabular}

Sumber : Data diolah, 2019

Tabel 3. dapat diketahui bahwa pada penelitian ini dari 132 responden penelitian, terdapat 58 orang (46,21\%) dengan umur 21-30 tahun, sebanyak 32 orang $(31,82 \%)$ dengan umur $31-40$ tahun, dan 29 orang $(21,97 \%)$ dengan umur lebih dari 40 tahun.

Hal ini memberikan informasi bahwa mayoritas responden yang merupakan komuter yang bepergian untuk bekerja dan beraktivitas secara rutin menggunakan kendaraan roda empat dari Denpasar atau ke Denpasaryang mendengarkan radio selama diperjalananmemiliki rentang umur berkisar 21-30 tahun. 
Tabel 4.

Karakteristik Responden Berdasarkan Pendidikan Terakhir

\begin{tabular}{ccc}
\hline Pendidikan Terakhir & Jumlah (orang) & Persentase (\%) \\
\hline SMA/SMK & 52 & 39,39 \\
Diploma & 34 & 25,76 \\
S1 & 41 & 31,06 \\
S2 & 5 & 3,79 \\
Total & $\mathbf{1 3 2}$ & $\mathbf{1 0 0}$ \\
\hline
\end{tabular}

Sumber : Data diolah, 2019

Tabel 4. berfungsi untuk mengetahui jenjang pendidikan yang dimiliki responden. Pada Tabel 4.5 responden yang memiliki tingkat pendidikan SMA/SMK sederajat sebanyak 52 orang (39,39\%), Diploma sebanyak 34 orang $(25,76 \%)$, S1 sebanyak 41 orang $(31,06 \%)$ dan S2 sebanyak 5 orang $(3,79 \%)$.

Hal ini menunjukkan bahwa komuter yang bepergian untuk bekerja dan beraktivitas secara rutin menggunakan kendaraan roda empat dari Denpasar atau ke Denpasaryang mendengarkan radio selama diperjalanan mayoritas memiliki jenjang pendidikan akhir paling banyak pada tingkat SMA/SMK sederajat.Dengan kata lain, mayoritas responden yang berpartisipasi dalam pengisian ini adalah seorang mahasiswa.

Tabel 5.

Karakteristik Responden Berdasarkan Radio yang Sering Didengarkan Selama Perjalanan

\begin{tabular}{cc}
\hline Radio & Jumlah (orang) \\
\hline Phoenix Radio (91,00 FM) & 94 \\
Cassanova Bali (102,00 FM) & 71 \\
d'Oz Radio Bali (101,2 FM) & 24 \\
Hard Rock FM (87,8 FM) & 18 \\
Lain-lain & 26 \\
\hline
\end{tabular}

Sumber : Data diolah, 2019

Tabel 5. menujukkan radio yang sering didengarkan oleh responden selama perjalanan dari atau ke Denpasar. Pada Tabel 4.6 responden yang sering mendengarkan Phoenix Radio (91,00 FM) sebanyak 94 orang, Cassanova Bali (102,00 FM) sebanyak 71 orang, d'Oz Radio Bali (101,2 FM) sebanyak 24 orang, Hard Rock FM (87,8 FM) sebanyak 18 orang dan radio lain-lain sebanyak 26 orang.

Hal ini menunjukkan bahwa Phoenix Radio Bali 91,00 FM memiliki awareness yang paling tinggi bagi para komuter yang bepergian untuk bekerja dan beraktivitas secara rutin menggunakan kendaraan roda empat dari Denpasar atau ke Denpasar.

Tabel 6. menujukkan iklan restoran yang pernah didengarkan oleh responden selama perjalanan dari Denpasar atau ke Denpasar. Pada Tabel 4.7 responden yang pernah mendengarkan iklan Hanamasa Restaurant sebanyak 29 orang $(21,9 \%)$, Cosmic Diner sebanyak 6 orang (4,5\%), Pizza Hut sebanyak 6 orang $(4,5 \%)$, ABC Artotel Sanur sebanyak 5 orang $(3,8 \%)$, dan sebanyak 95 (71,9\%) orang responden menjawab iklan restoran yang berbeda-beda sehingga dikategorikan keiklan restoran lain-lain. Untuk menguji instrumen penelitian dilakukan uji validasi dan 
uji reliabiltas sebelum data dianalisis lebih lanjut. Hasil uji validitas dapat dilihat pada Tabel 7.

Tabel 6.

Karakteristik Responden Berdasarkan Iklan Restoran yang Pernah Didengarkan Selama Perjalanan

\begin{tabular}{ccc}
\hline Iklan Restoran & Jumlah (orang) & Persentase (\%) \\
\hline Hanamasa Restaurant & 29 & 21,9 \\
Cosmic Diner & 6 & 4,5 \\
Pizza Hut & 6 & 4,5 \\
ABC Artotel Sanur & 5 & 3,8 \\
Lain-lain & 95 & 71,9 \\
\hline Sumber : Data diolah 2019 & &
\end{tabular}

Tabel 7.

Hasil Uji Validitas

\begin{tabular}{cccc}
\hline Variabel & Indikator & Koefisien Korelasi & Keterangan \\
\hline \multirow{6}{*}{ Iklan radio $\left(\mathrm{X}_{1}\right)$} & $\mathrm{X} 1.1 .1$ & 0,563 & Valid \\
& $\mathrm{X} 1.1 .2$ & 0,816 & Valid \\
& $\mathrm{X} 1.13$ & 0,491 & Valid \\
& $\mathrm{X} 1.2 .1$ & 0,866 & Valid \\
& $\mathrm{X} 1.2 .2$ & 0,853 & Valid \\
& $\mathrm{X} 1.3 .1$ & 0,927 & Valid \\
& $\mathrm{X} 1.3 .2$ & 0,747 & Valid \\
& $\mathrm{X} 1.4 .1$ & 0,748 & Valid \\
& $\mathrm{X} 1.4 .2$ & 0,774 & Valid \\
& $\mathrm{X} 2.1 .1$ & 0,619 & Valid \\
Sikap $\left(\mathrm{X}_{2}\right)$ & $\mathrm{X} 2.1 .2$ & 0,904 & Valid \\
& $\mathrm{X} 2.1 .3$ & 0,629 & Valid \\
& $\mathrm{X} 2.2 .1$ & 0,904 & Valid \\
& $\mathrm{X} 2.2 .2$ & 0,836 & Valid \\
Pencarian informasi $\left(\mathrm{X}_{3}\right)$ & $\mathrm{X}_{3.2 .3}$ & 0,761 & Valid \\
& $\mathrm{X}_{3.1}$ & 0,806 & Valid \\
& $\mathrm{X}_{3.2}$ & 0,816 & Valid \\
& $\mathrm{X}_{3.3}$ & 0,813 & Valid \\
Pilihan Restoran & $\mathrm{Y}_{1}$ & 0,562 & Valid \\
(Y) & $\mathrm{Y}_{2}$ & 0,741 & Valid \\
& $\mathrm{Y}_{3}$ & 0,564 & Valid \\
& $\mathrm{Y}_{4}$ & 0,684 & Valid \\
\hline
\end{tabular}

Sumber : Data diolah, 2019

Hasil uji validitas pada Tabel 7. diatas menunjukkan bahwa seluruh variabel memiliki nilai koefisien korelasi dengan skor total seluruh item pernyataan lebih besar dari 0,30. Berdasrkan hal tersebut dapat disimpulkan bahwa butir-butir pernyataan dalam instrument penelitian tersebut valid.

Setelah dilakukan uji validitas, langkah selanjutnya adalah melakukan uji reliablitias data yaitu dengan melihat nilai Cronbach's Alpha. Hasil uji rabilitas dapat dilihat pada Tabel 8 . 
Tabel 8.

Hasil Uji Reliabilitas

\begin{tabular}{clcc}
\hline No. & \multicolumn{1}{c}{ Variabel } & Cronbach's Alpha & Keterangan \\
\hline 1 & Iklan radio $\left(\mathrm{X}_{1}\right)$ & 0,795 & Reliabel \\
2 & Sikap $\left(\mathrm{X}_{2}\right)$ & 0,894 & Reliabel \\
3 & Pencarian informasi $\left(\mathrm{X}_{3}\right)$ & 0,830 & Reliabel \\
4 & Pilihan restoran $(\mathrm{Y})$ & 0,735 & Reliabel \\
\hline \multicolumn{2}{l}{ Sumber $:$ Data diolah, 2019}
\end{tabular}

Hasil uji reliabilitas pada Tabel 8. menunjukkan bahwa seluruh instrumen penelitian memiliki koefisien Cronbach's Alpha lebih dari 0,60. Berdasarkan hal tersebut maka dapat disimpulkan bahwa semua instrumen reliabel sehingga dapat digunakan untuk melakukan penelitian.

Tabel 9.

Hasil Uji Normalitas

\begin{tabular}{lc}
\hline & Unstandardized Residual \\
\hline $\mathrm{N}$ & 132 \\
Kolmogorov-Smirnov Z & 0,646 \\
Asymp. Sig. (2-tailed) & 0,799 \\
\hline
\end{tabular}

Sumber: Data diolah, 2019.

Tabel 9. menunjukkan bahwa nilai Kolmogorov Sminarnov (K-S) sebesar 0,646, sedangkan nilai Asymp. Sig. (2-tailed) sebesar 0,799. Hasil tersebut mengindikasikan bahwa model persamaan regresi tersebut berdistribusi normal karena nilai Asymp. Sig. (2-tailed) 0,799lebih besar dari nilai alpha 0,05.

Tabel 10.

Hasil Uji Multikolinieritas

\begin{tabular}{|c|c|c|}
\hline Variabel & Tolerance & VIF \\
\hline Iklan radio $\left(\mathrm{X}_{1}\right)$ & 0,276 & 3,625 \\
\hline $\operatorname{Sikap}\left(\mathrm{X}_{2}\right)$ & 0,241 & 4,145 \\
\hline Pencarian informasi $\left(\mathrm{X}_{3}\right)$ & 0,415 & 2,407 \\
\hline
\end{tabular}

Sumber: Data diolah, 2019

Tabel 10. menunjukkan bahwa nilai tolerance pada masing-masing variabel lebih besar dari 10\% $(0,1)$, demikian pula dengan nilai VIF masing-masing variabel yang lebih kecil dari 10. Hal ini menandakan bahwa pada persamaan regresi linier berganda dengan variabel dependen nilai perusahaan ini tidak terdapat kolerasi antar variabel bebas sehingga persamaan ini bebas dari gejala multikolinearitas.

Tabel 11.

Hasil Uji Autokorelasi

\begin{tabular}{cccccc}
\hline No & dl & Du & 4-du & DW & Simpulan \\
\hline 1 & 1,6696 & 1,7624 & 2,2376 & 1,845 & Bebas autokorelasi \\
\hline Sumber: & Data & diolah 2019 & & &
\end{tabular}

Sumber: Data diolah, 2019

Tabel 11. menunjukkan bahwa besarnya nilai Durbin Watson sebesar 1,845. Nilai $\mathrm{D}-\mathrm{W}$ menurut tabel dengan $\mathrm{n}=132$ dan $\mathrm{k}=3$ didapat nilai $\mathrm{dl}=1,6696$ dan nilai 
$\mathrm{du}=1,7624$. Oleh karena nilai $\mathrm{du}<\mathrm{dw}<(4-\mathrm{du})$ yaitu $(1,7624<1,845<2,2367)$, maka dapat disimpulkan tidak terdapat autokorelasi antar residual.

Tabel 12.

Hasil Uji Heteroskedastisitas

\begin{tabular}{|c|c|c|c|c|c|}
\hline & \multicolumn{2}{|c|}{$\begin{array}{l}\text { Unstandardized } \\
\text { Coefficients }\end{array}$} & \multirow{2}{*}{$\begin{array}{l}\text { Standardized } \\
\text { Coefficients } \\
\text { Beta } \\
\end{array}$} & \multirow[b]{2}{*}{$\mathbf{T}$} & \multirow[b]{2}{*}{ Sig. } \\
\hline & B & Std. Error & & & \\
\hline (Constant) & 0,036 & 1,308 & & 0,028 & 0,978 \\
\hline Iklan radio & 0,006 & 0,027 & 0,039 & 0,233 & 0,816 \\
\hline Sikap & 0,009 & 0,043 & 0,038 & 0,212 & 0,833 \\
\hline Pencarian informasi & 0,061 & 0,058 & 0,141 & 1,037 & 0,302 \\
\hline Interaksi X1.X2 & 0,000 & 0,001 & $-0,066$ & $-0,343$ & 0,732 \\
\hline Interaksi X1.X3 & 0,001 & 0,000 & 0,130 & 1,339 & 0,183 \\
\hline
\end{tabular}

Sumber: Data diolah, 2019

Tabel 12. menunjukkan bahwa bahwa nilai signifikansi dari variabel iklan radio sebesar 0,816, Sikap sebesar 0,833, pencarian informasi sebesar 0,302, variabel interaksi X1.X2 sebesar 0,732 dan variabel interaksi X1.X3 sebesar 0,183. Nilai tersebut lebih besar dari 0,05 yang berarti tidak terdapat pengaruh antara variabel bebas terhadap absolute residual. Dengan demikian, model yang dibuat tidak mengandung gejala heteroskedastisitas.

Tabel 13.

Hasil Analisis Regresi Moderasi

\begin{tabular}{|c|c|c|c|c|c|}
\hline \multirow[t]{2}{*}{ Model } & \multicolumn{2}{|c|}{$\begin{array}{c}\text { Unstandardized } \\
\text { Coefficients }\end{array}$} & \multirow{2}{*}{$\begin{array}{c}\begin{array}{c}\text { Standardized } \\
\text { Coefficients }\end{array} \\
\text { Beta } \\
\end{array}$} & \multirow[b]{2}{*}{$\mathbf{t}$} & \multirow[b]{2}{*}{ Sig. } \\
\hline & B & Std. Error & & & \\
\hline (Constant) & 0,309 & 2,078 & & 0,149 & 0,882 \\
\hline Iklan radio (X1) & 0,115 & 0,042 & 0,223 & 2,721 & 0,007 \\
\hline Sikap (X2) & 0,032 & 0,068 & 0,042 & 0,476 & 0,635 \\
\hline Pencarian informasi (X3) & 0,129 & 0,093 & 0,093 & 1,390 & 0,167 \\
\hline Interaksi X1.X2 & 0,010 & 0,001 & 0,660 & 6,967 & 0,000 \\
\hline Interaksi X1.X3 & 0,002 & 0,001 & 0,148 & 3,118 & 0,002 \\
\hline R Square & & 0,766 & & & \\
\hline Adjusted R Square & & 0,756 & & & \\
\hline F Statistik & & 82,353 & & & \\
\hline Signifikansi & & $\mathbf{0 , 0 0 0}$ & & & \\
\hline
\end{tabular}

Sumber : Data diolah, 2019

Interpretasi dari persamaan di atas adalah sebagai berikut : Nilai konstanta sebesar 0,309 yaitu jika iklan radio $\left(\mathrm{X}_{1}\right)$, Sikap $\left(\mathrm{X}_{2}\right)$, pencarian informasi $\left(\mathrm{X}_{3}\right)$, interaksi iklan radio dengan Sikap dan interaksi iklan radio dengan pencarian informasisama dengan nol, maka nilai pilihan restoran, dengan asumsi variabel lainnya konstant atau tetap, maka pilihan restoran adalah sebesar 0,309 satuan.

Koefisien regresi iklan radio sebesar 0,115artinya apabila iklan radio meningkat sebesar 1 satuan dengan anggapan variabel lainnya konstan, maka pilihan restoran akan meningkat sebesar 0,115 satuan

Koefisien regresi sikap sebesar 0,032 artinya apabila sikap komuter meningkat sebesar 1 satuan dengan anggapan variabel lainnya konstan, maka 
pilihan restoran akan meningkat sebesar 0,032 satuan. Koefisien regresi pencarian informasi sebesar 0,129 artinya apabila pencarian informasi meningkat sebesar 1 satuan dengan anggapan variabel lainnya konstan, maka pilihan restoran akan meningkat sebesar 0,129 satuan. Koefisien regresi interaksi X1.X2 sebesar 0,010 artinya setiap kenaikan interaksi X1.X2 sebesar 1 satuan akan menyebabkan peningkatan pada pilihan restoran sebesar 0,010 satuan. Koefisien regresi interaksi X1.X3 sebesar 0,002 artinya setiap kenaikan interaksi X1.X3 sebesar 1 satuan akan menyebabkan peningkatan pada pilihan restoran sebesar 0,002 satuan.

Hasil uji F (Ftest) pada Tabel 13 menunjukkan bahwa besarnya nilai $\mathrm{F}$ hitung sebesar 82,353 dengan nilai signifikansi $P_{\text {value }} 0,000$ lebih kecil dari $\alpha=0,05$, yang mengindikasikan bahwa model yang digunakan pada penelitian ini adalah layak. Hasil ini memberikan makna bahwa seluruh variabel independen mampu memprediksi atau menjelaskan fenomena pilihan restoran pada komuter Kota Denpasar.

Dengan kata lain iklan radio $\left(\mathrm{X}_{1}\right)$, Sikap $\left(\mathrm{X}_{2}\right)$, pencarian informasi $\left(\mathrm{X}_{3}\right)$, interaksi iklan radio dengan sikap dan interaksi iklan radio dengan pencarian informasisecara simultan berpengaruh signifikan terhadap pilihan restoranpada komuter yang mendengarkan radio saat bepergian dari Denpasar maupun ke Denpasar.

Hasil uji koefisien determinasi $\left(\mathrm{R}^{2}\right)$ menunjukkan perolehan besarnya adjusted $\mathrm{R}^{2}$ (koefisien determinasi yang telah disesuaikan) pada Tabel 13 adalah 0,756 . Hal tersebut menunjukkan bahwa variasi pilihan restoran dapat dijelaskan oleh variabel iklan radio $\left(\mathrm{X}_{1}\right)$, Sikap $\left(\mathrm{X}_{2}\right)$, pencarian informasi $\left(\mathrm{X}_{3}\right)$, interaksi X1.X2dan interaksi X1.X3sebesar 75,6 persen, sedangkan sisanya sebesar 24,4 persen dijelaskan oleh faktor-faktor lain yang tidak dijelaskan dalam model penelitian.

Pengaruh secara parsial pada variabel iklan radio $\left(X_{1}\right)$, Sikap $\left(X_{2}\right)$, pencarian informasi $\left(\mathrm{X}_{3}\right)$, interaksi iklan radio dengan sikap $\left(\mathrm{X}_{1} . \mathrm{X}_{2}\right)$ dan interaksi iklan radio dengan pencarian informasi $\left(\mathrm{X}_{1} . \mathrm{X}_{3}\right)$ diuji dengan menggunakan uji regresi moderasi yang ditinjau berdasarkan nilai t hitung pada Tabel coeffisient. Kriteria pengujian untuk menjelaskan interpretasi pengaruh antar masing-masing variabel yakni jika nilai signifikansi $<0,05$ maka $\mathrm{H}_{0}$ ditolak dan $\mathrm{H}_{1}$ diterima. Sebaliknya, jika nilai signifikansi $>0,05$ maka $\mathrm{H}_{0}$ diterima dan $\mathrm{H}_{1}$ ditolak.

Berdasarkan uji statistik pengaruh iklan radio pada pilihan menunjukkan koefisien regresi positif sebesar 0,115 dengan $P_{\text {value }} 0,007<0,050$. Hasil uji tersebut menunjukkan bahwaH ${ }_{1}$ diterima, yaitu iklan radio berpengaruh positif dan signifikan pada pilihan restoran.

Berdasarkan uji statistik menunjukkan interaksi X1.X2 antara iklan radio dengan sikap menunjukkan koefisien regresi positif sebesar 0,010 dengan $\mathrm{P}_{\text {value }}$ $0,000<0,050$. Hasil uji tersebut menunjukkan bahwa $\mathrm{H}_{2}$ diterima yaitu sikap memoderasi pengaruh iklan radio terhadap pilihan restoran secara positif.

Berdasarkan uji statistik menunjukkan interaksi X1.X3 antara iklan radio dengan pencarian informasi menunjukkan koefisien regresi positif sebesar 0,002 dengan $\mathrm{P}_{\text {value }} 0,002<0,050$. Hasil uji tersebut menunjukkan bahwa $\mathrm{H}_{3}$ diterima yaitu pencarian informasi memoderasi pengaruh iklan radio terhadap pilihan restoran secara positif. 
Hasil analisis dalam penelitian ini menunjukkan bahwa iklan radio berpengaruh positif dan signifikan pada pilihan restoran. Hal ini menunjukkan bahwa semakin baik dan menarik penyampaian informasi mengenai restoranpada iklan radio, maka akan memberi dampak positif pada probabilitas pilihan restoran yang dilakukan oleh komuter Kota Denpasar. Begitu juga sebaliknya semakin buruk penyampaian informasi mengenai restoranpada iklan radio, maka akan menurunkan probabilitas pilihan restoran yang dilakukan oleh komuter Kota Denpasar.

Hasil penelitian ini mendukung hasil penelitian yang dilakukan oleh Rajagopal (2011) yang menyatakan bahwa iklan radio menembus dengan cepat dan memberi efek positif pada pendengar untuk menentukan pilihan toko atau restoran dan probabilitas pembelian. Hasil penelitian ini juga sejalan dengan temuan Volle (2001), Auty (2006) yang memperoleh hasil bahwa iklan radio merupakan hal yang paling mungkin memengaruhi pilihan restoran para konsumen, maka iklan radio harus jelas dan terdengar untuk memotivasi faktor-faktor untuk mempengaruhi perilaku pembelian pelanggan.

Hasil analisis regresi moderasi menunjukkan bahwa sikap secara statistik mampu memoderasi pengaruh iklan radio terhadap pilihan restoran. Pada penelitian ini, sikap memperkuat pengaruh iklan radio terhadap pilihan restoran. Hal ini menunjukkan apabila komuter memiliki sikap yangp ositif pada iklan restoran yang disiarkan dalam radio,makakomuter akan merasa tertarik untuk mencari informasi terkait restoran tersebut sehingga dapat mempermudah komuter dalam menentukan pilihan restoran yang tepat.

Sebaliknya, apabila komuter memilikisikap yangnegatif pada iklan restoran yang disiarkan dalam radio,makakomuter tidak akanmerasa tertarik untuk mencari informasi lebih lanjut terkait restoran tersebut sehingga tidak dapat mempermudah komuter dalam menentukan pilihan restoran yang tepat.

Hasil penelitian ini didukung oleh temuan Wahid \& Ahmed (2011) yang menyatakan bahwa sikap konsumen terhadap periklanan berpengaruh signifikan dan positif atas niatnya untuk membeli produk yang diiklankan, sehingga hal tersebut akan cenderung meningkatkan probabilitas konusmen dalam menentukan restoran yang akan dipilih. Hasil penelitian ini juga didukung oleh penelitian Rajagopal (2011), Ansari \& Joloudar (2014) dan Kaushal \& Rakesh (2016) yang menyatakan bahwa sikap memperkuat pengaruh iklan terhadap pilihan produk konsumen.

Hasil analisis regresi moderasi menunjukkan bahwa pencarian informasi secara statistik mampu memoderasi pengaruh iklan radio terhadap pilihan restoran. Pada penelitian ini, pencarian informasi memperkuat pengaruh iklan radio terhadap pilihan restoran.

Hal ini menunjukkan apabila komuter memilikipencarian informasi yang tinggi mengenai suatu restoran,makakomuter akan merasa tertarik untuk mendengarkan iklan yang disiarkan dalam radio terkait informasi restoran sehingga komuter memperoleh informasi yang lengkap mengenai restoran dan dapat membantu komuter menentukan pilihan restoran yang tepat.

Sebaliknya, apabila komuter tidak sedang melakukan pencarian informasi mengenai suatu restoran,makakomuter tidak akan merasa tertarik untuk 
mendengarkan iklan yang disiarkan dalam radio terkait informasi restoran sehingga tidak ada restoran yang akan dipilih oleh komuter.

Hasil penelitian ini didukung oleh temuan Rajagopal (2011) menyatakan bahwa penyiaran iklan di radio memberi dampak positif bagi penumpang perkotaan untuk memahami komunikasi dengan memperhatikan dan berbagi informasi yang menunjukkan kesadaran akan isi komunikasi..

Hasil penelitian ini juga didukung oleh penelitian Volle (2001) menyatakan bahwa efek dari jumlah produk yang diajukan dalam selebaran pada probabilitas pilihan restoran akan lebih tinggi bagi pelanggan yang mengklaim mencari informasi promosi.

Hasil penelitian serupa oleh Pedraja \& Yague (2001), Marta (2001), Hsu \& Mo (2009) dan Rosenbloom \& Jiang (2014) juga menyatakan bahwa pencarian informasi memperkuat pengaruh iklan terhadap pilihan produk konsumen.

Penelitian yang dilakukan diharapkan dapat memberikan kontribusi mengenai pengaruh iklan radio terhadap pilihan restoran dengan sikap dan pencarian informasi sebagai variabel pemoderasi. Hasil uji hipotesis dalam penelitian ini ditemukan bahwa variabel sikap dan pencarian informasi secara statistik mampu memoderasi pengaruh iklan radio terhadap pilihan restoran bagi komuter di Kota Denpasar, sehingga variabel tersebut dapat dipertahankan sebagai variabel pemoderasi.

Penelitian ini memberikan implikasi bagi penyiar radio sebagai pertimbangan dan pengetahuan mengenai pilihan restoran serta faktor-faktor yang memengaruhinya. Perusahaan dapat mengevaluasi sikap dan pencarian informasi komuter, karena hal tersebut dapat mempengaruhi pilihan restoran.

\section{SIMPULAN}

Simpulan yang dapat diberikan berdasarkan hasil penelitian yang dilakukan yaitu: Iklan radio berpengaruh positif dan signifikan pada pilihan restoran. Hal ini menunjukkan bahwa semakin baik dan menarik penyampaian informasi mengenai restoran pada iklan radio, maka akan memberi dampak positif pada probabilitas pilihan restoran yang dilakukan oleh komuter Kota Denpasar. Sikap secara statistik mampu memoderasi pengaruh iklan radio terhadap pilihan restoran. Pada penelitian ini, sikap memperkuat pengaruh iklan radio terhadap pilihan restoran. Hal ini menunjukkan apabila komuter memiliki sikap yang positif pada iklan restoran yang disiarkan dalam radio,maka komuter akan merasa tertarik untuk mencari informasi terkait restoran tersebut sehingga dapat mempermudah komuter dalam menentukan pilihan restoran yang tepat. Pencarian informasi secara statistik mampu memoderasi pengaruh iklan radio terhadap pilihan restoran.

Pada penelitian ini, pencarian informasi memperkuat pengaruh iklan radio terhadap pilihan restoran. Hal ini menunjukkan apabila komuter memiliki pencarian informasi yang tinggi mengenai suatu restoran,maka komuter akan merasa tertarik untuk mendengarkan iklan yang disiarkan dalam radio terkait informasi restoran sehingga komuter memperoleh informasi yang lengkap mengenai restoran dan dapat membantu komuter menentukan pilihan restoran yang tepat. Berdasarkan hasil penelitian, analisis, serta kesimpulan di atas, maka saran yang dapat diberikan sebagai berikut: Dalam upaya meningkatkan fungsi iklan radiobagi komuter, maka 
sebaiknya iklan radio yang diputar dibuat dengan lebih menarik dan membuat komuter penasaran untuk mencari informasi terkait restoran yang diiklankan sehingga pada akhirnya dapat mempengaruhi keputusan pembelian yang akan dilakukan komuter. Dalam upaya meningkatkansikap positifkomuter terhadap informasi yang disampaikan iklan radio, maka penyiar radio di Kota Denpasar sebaiknya membuat program interaktif yang menarik dengan komuter agar tumbuh perasaan suka dan senang pada komuter untuk mendengarkan iklan radio tersebut. Selain itu penting bagi penyiar radio memberikan informasi penting yang dapat membantu komuter.

Dalam upaya meningkatkan pencarian informasipada iklan radio menjadi semakin meningkat, maka penyiar radio di Kota Denpasar sebaiknya membuat inovasi penyampaian informasi yang unik bagi komuter, agar komuter mempriorotaskan iklan radio sebagai sumber informasi utama.

\section{REFERENSI}

Ansari, M. E., \& Joloudar, Y. E. (2014). An Investigation of TV Advertisement Effects on Customers. International Journal of Marketing Studies, 5(2), 175181. https://doi.org/http://dx.doi.org/10.5539/ijms.v3n4p175

Auty, S. (2006). Consumer Choice And Segmentation In The Restaurant Industry. The Service Industries Journal, 12(1), 324-339. https://doi.org/https://doi.org/10.1080/02642069200000042

Badan Pusat Statistik. (2016). Perkembangan Jumlah Kendaraan Bermotor Menurut Jenis. Retrieved from https://www.bps.go.id/linkTableDinamis/view/id/1133

Hsu, J. L., \& Mo, R. H. (2009). Consumer Responses To Incomplete Information In Print Apparel Advertising. Journal of Fashion Marketing and Management: An International Journal, 13(1), 66-78. https://doi.org/https://doi.org/10.1108/13612020910939888

Kaushal, S. K. K., \& Rakesh. (2016). Influence of Attitude towards Advertisement on Purchase Intention: Exploring the Mediating Role of Attitude towards Brand Using SEM Approach. IUP Journal of Marketing Management, 15(4), 44-59. Retrieved from https://ssrn.com/abstract $=3075718$

Köksal, M. H. (2011). The Variables Influencing Consumer Information Search Strategies. International Journal of Retail \& Distribution Management, 39(10), 726-741. https://doi.org/https://doi.org/10.1108/09590551111162239

Kotler, P., \& Keller, K. L. (2012). Marketing Management 14e. New Jersey: Pearson. 
Loechner, J. (2016). 90\% of Car Commuters Are Listening To The Radio. Retrieved from Media Post website: https://www.mediapost.com/publications/ article/274139/90-of-carcommuters-are-listening-to-the-radio.html

Marta. (2001). What Information do Customers use when choosing a Restaurant? International Journal of Contemporary Hospitality Management, 13(6), 316318. https://doi.org/https://doi.org/10.1108/EUM0000000005966

Oakes, S., \& North, A. C. (2011). The Impact Of Narrator Age Congruity On Responses To A Radio Advertisement. Journal of Marketing Communications, 17(3), 183-194. https://doi.org/https://doi.org/10.1080/13527260903411780

Pedraja, M., \& Yague, J. (2001). What Information Do Customers Use When Choosing A Restaurant?. International Journal of Contemporary Hospitality Management, $13(1)$

316-318. https://doi.org/https://doi.org/10.1108/EUM0000000005966

Perner, L. (2010). Consumer Behavior: The Psychology Of Marketing.

Rajagopal. (2011). Impact Of Radio Advertisements On Buying Behaviour Of Urban Commuters. International Journal of Retail \& Distribution Management, 39(7), 480-503.

Raju, A., \& Devi, P. S. (2012). Means of Advertisement Impact on Consumer Buying Behaviour With Reference to Health Drinks in Kuppam. International Journal of Management and Social Sciences Research (IJMSSR), $\quad 1(2), \quad 31 \quad-35$. https://doi.org/http://www.irjcjournals.org/ijmssr/nov2012/8.pdf

Roehm, M. . (2001). Instrumental Vs Vocal Versions Of Popular Music In Advertising. Journal of Advertising Research, 41(3), 49-58. https://doi.org/http://dx.doi.org/10.2501/JAR-41-3-49-58

Rosenbloom, B., \& Jiang, P. (2014). Consumer Knowledge and External PrePurchase Information Search: A Meta-Analysis of the Evidence. Consumer Culture Theory. Journal Research in Consumer Behavior, 15(1), 353 - 389. https://doi.org/https://www.emeraldinsight.com/doi/abs/10.1108/S0885$2111 \% 282013 \% 290000015023$

Thang, D. C. L., \& Tan, B. L. B. (2003). Linking Consumer Perception To Preference Of Retail Stores:An Empirical Assessment Of The MultiAttributes Of Store Image. Journal of Retailing and Consumer Services, 10(1), 193-200. $\quad \mathrm{https}$ ://doi.org/https://doi.org/10.1016/S09696989(02)00006-1 
Tripathi, S., \& Sinha, P. K. (2008). Choice of a Retail Store and Retail Store Format: A Hierarchical Logit Model. Research and Publications Indian Institute of Management Ahmedabad, India, 1(1), 1-20.

Volle, P. (2001). The Short-Term Effect Of Store-Level Promotions On Store Choice, And The Moderating Role Of Individual Variables. Journal of Business Research, 53(2), 63-75. https://doi.org/https://doi.org/10.1016/S0148-2963(99)00074-0

Wahid, N. A., \& Ahmed, M. (2011). The Effect of Attitude toward Advertisement on Yemeni Female Consumers' Attitude toward Brand and Purchase Intention. Global Business and Management Research, 3(1), 21-29. https://doi.org/https://trove.nla.gov.au/work/152925505

Yeoh, P. (2005). A Conceptual Framework Of Antecedents Of Information Search In Exporting: Importance Of Ability And Motivation. International Marketing Review, 22(2), 165-198. https://doi.org/https://doi.org/10.1108/02651330510593269 